\title{
Hypoglycemic effect of okra aqueous extract on streptozotocin-induced diabetic rats
}

\author{
Li WU ${ }^{1,2,}$, Minjie WENG ${ }^{1,2}$, Hengguang ZHENG ${ }^{1,2}$, Pufu LAI ${ }^{1,2}$, Baosha TANG $^{1,2}$, Junchen CHEN $^{1,2}$, Yibin LI $^{1,2 *}$ (D)
}

\begin{abstract}
Okra (AbelmoschusesculentusL.Moench) is widely planted in subtropical and tropical areas, with good palatability and a variety of biological activities. However, the hypoglycemic activity of okra aqueous extract and its mechanism were still unclear. In this paper, the hypoglycemic effect of okra aqueous extract on type 1 diabetic rats induced by streptozotocin (STZ) was investigated. The growth indicators, blood physiological and biochemical indicators (such as blood glucose, glucose tolerance, serum lipids, insulin, pyruvate kinase activity), histopathology of liver and pancreas were determined. Comparing with streptozotocin-induced diabetic rats group, the aqueous extract of okra treatment group exhibited decreasing blood glucose level (10.11\%), glucose tolerance $(12.00 \%)$, total triglyceride $(41.59 \%)$, atherosclerosis index $(49.20 \%)$, urine sugar $(91.91 \%)$ and increasing insulin secretion (17.44\%) and pyruvate kinase activity (57.41\%). Okra aqueous extract significantly ameliorated STZ-induced steatosis of hepatocytes and islet cells. But, the feed intake, water intake, urine volume, and body weight of okra aqueous extract treated groups were not significantly different with those in normal rats groups or diabetic rats group, respectively. Therefore, the aqueous extract of okra was responsible for promoting insulin secretion, increasing pyruvate kinase activity and reducing blood glucose and lipid level.
\end{abstract}

Keywords: okra; aqueous extract; hypoglycemic activity; hypolipidemic activity.

Practical Application: The aqueous extract of okra can be potentially used as natural hypoglycemic and hypolipidemic food resource.

\section{Introduction}

Diabetes mellitus (DM) is one of the common metabolic diseases in human. According to World Health Organization (WHO), it was forecasted that there are probably 439 million diabetes by 2030 (Shaw et al., 2010).About $10 \%$ of clinical diabetic patients are reported to be type 1 diabetes mellitus (T1DM), named as insulin-dependent diabetes mellitus (IDDM) (Gero, 2010; Lillioja, 1999; O'Callaghan, 2017).T1DM results from the insufficient insulin secretion of pancreatic $\beta$ cells induced by viruses, chemical toxins, diet, and autoimmune responses(Lee et al., 2010). T1DM is characterized by high glucose and low insulin, and absolute insulin deficiency rather than insulin resistance is the main pathphysiological mechanism behind chronic hyperglycemia (Fellinger et al., 2019). Glycemic abnormalities are often accompanied by disorders of lipid metabolism (Lv et al., 2019; Guo et al.,2018). In recent years, regulation of disorders of glucose and lipid metabolism have become hot research topics (Hu et al., 2018; Li et al., 2019).

Okra (AbelmoschusesculentusL.Moench), also named as lady's finger or gumbo, is an African native plant. It is currently widely grown in tropical and subtropical regions (Gao et al., 2018; Sahoo \& Srivastava, 2002). On the basis of the statistics of the UN Food and Agriculture Organization in 2017, the global okra production reached 9.64 million tons, and the trade volume exceeded 5 billion dollars (Food and Agriculture Organization of the United Nations, 2017). In recent years, okra has large-scale planted in Hainan and Fujian Province, China, but the comprehensive utilization of okra extraction was still in its infancy (Tang et al., 2017; Weng et al., 2017). The okra extracts referred to a substance obtained by hot water, acid solution and/or alcohol solution, was a natural, non-toxic and inexpensive food and medicine material. At present, most of the studies on okra water-soluble extracts, which were rich in bioactive polysaccharides (Georgiadis et al., 2011) (the content of polysaccharide in okra was 10.35\%) (Yuan et al., 2019), and the polysaccharide sugar chains were composed of glucose, galactose, rhamnose, galacturonic acid and glucuronic acid (Deters et al., 2005). Besides supplying common nutrients like protein and fat, it is also a good source of antioxidantive flavonoids and dietary fibers with the effect of stimulating intestinal peristalsis and preventing constipation (Adetuyi\& Ibrahim, 2014; Kahlon et al., 2007). It has been reported that the various parts of okra have hypoglycemic and hypolipidemic activities in diabetic rats induced by streptozotocin (Sabitha et al., 2011). Some reports have demonstrated that okra can cut down blood glucose level and lipid level in obese mice induced by high-fat diet (Fan et al., 2014). Okra is used as a dietary therapy for type 2 diabetes mellitus complicated with blindness, cataract and glaucoma (Moïse et al., 2012; Sardá et al., 2018). These evidences indicate that okra may play an important part in the adjustment glycolipid metabolism. However, the hypoglycemic 
activity of okra aqueous extract and its mechanism on normal rats and type 1 diabetic rats were still unclear.

Therefore, in the present work, the aqueous ingredients were extracted from okra, and the antidiabetic effect of okra aqueous extract on streptozotocin-induced type 1 diabetes rats were measured.

\section{Materials and methods}

\subsection{Materials}

The aqueous extract

The fresh and mature okra pods were cut into a thickness of $2-3 \mathrm{~cm}$, and then dried by a heat pump at $60^{\circ} \mathrm{C}$ to obtain a dried okra having a moisture content of $13 \%$. $1 \mathrm{~kg}$ dried okra added $25 \mathrm{~kg}$ of distilled water. The okra mixture was heated to 100 and then held for 2 hours on the induction cooker (Dongguan Xinxin Thermal Energy Technology Co., Ltd.). The extract was coarsely filtered with 2 layers of gauze and centrifuged at $3500 \mathrm{rpm}$ for 10 min with a centrifuge (GL10MD, Hunan Xiangyi Laboratory Development Co., Ltd.).The supernatant was combined and concentrated to 1/3-1/4 volume by a rotary evaporator (RE5220, Shanghai Yarong Biochemical Instrument Factory) at $60{ }^{\circ} \mathrm{C}$, $30 \mathrm{rpm}$. The concentrated liquid was freeze-dried by a freeze dryer (SCIENTZ-30ND, Ningbo Xinzhi Biotechnology Co., Ltd.). At last 511.0g okra aqueous extract was obtained for further experiment. The okra aqueous extract is mainly composed of polysaccharide $11.16 \%$, flavonoids $1.17 \%$, pectin $2.01 \%$, ash $14.55 \%$ and water $8.90 \%$. The molecular weight distribution of okra extract is mainly composed of a small molecule with a molecular weight of $2124(80.35 \%)$ and two polysaccharides with molecular weight of 2.539 million (10.37\%) and molecular weight of $74,000(9.28 \%)$, respectively.

\section{Reagents}

Total cholesterol (TC), triglyceride (TG), high-density lipoprotein cholesterol (HDL-C), low-density lipoprotein cholesterol (LDL-C) kit and insulin test kit were purchased from Jiancheng Biological Engineering Institute, Nanjing, China. Streptozotocin was produced by Sigma company; Blood glucose test paper produced by Germany Roche diagnostics co., LTD. Glucose and other reagents are AR grade.

\subsection{Experimental design}

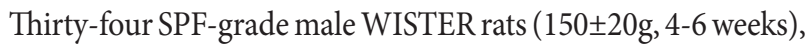
with a body weight of $220 \pm 20 \mathrm{~g}$ after 10 days of accommodation, were bought from Shanghai Slaccas Laboratory Animal Company Limited (Certificate Number SCXK(hu)2017-0005, Shanghai, China). The T1DM rat model was established according to the method of the State Food and Drug Administration (The State Food and Drug Administration, 2012), with minor modifications. After a accommodation period for 10 days, all the rats (excepted 12 rats set as normal control group) were fasted for 24 hours (free drinking water) and injected intraperitoneally with streptozotocin at a dose of $40 \mathrm{mg} / \mathrm{kg}$ body weight (b.w.). STZ is dissolved in $0.1 \mathrm{M}$ cold citrate buffer at $\mathrm{pH} 4.5$ before using. Five days after STZ induction, the blood samples were collected from the tail vein of the 5 hours fasted rats. Rats with FBG concentrations between $11.1-25.0 \mathrm{mmol} / \mathrm{L}$ were considered as diabetic rats and used in the study. Rats were randomly divided into 4 groups as follows: Group I(CK): normal rats receiving sterile distilled water $(n=6)$; Group II(CKO): normal rats treated with $500 \mathrm{mg} / \mathrm{kg}$ b.w./d of okra aqueous extract $(n=6)$; GroupIII $(M)$ : diabetic rats receiving sterile distilled water ( $n=9)$; Group IV(MO): diabetic rats treated with $500 \mathrm{mg} / \mathrm{kg}$ b.w./d of okra aqueous extract $(\mathrm{n}=9)$. The aqueous extract of okra were dissolved in sterile distilled water and intragastrically administered for 8 weeks. The rats used in the present study were approved by the Animal Ethics Committee of the Fujian Academy of Traditional Chinese Medicine (Fuzhou, China).

During the experimental period, feed intake, water intake of each cage were weighed daily, and weight measured weekly, and FBG were measured from the tail vein of the 5 hours fasted rats weekly. Glucose tolerance test according to the method of The State Food and Drug Administration (2012). After 4 weeks of treatment, rats fasted overnight and FBG were determined with Roche glucometer (Shanghai, China). For oral glucose tolerance test (OGTT), the rat blood samples were collected and determined at 0,30 and $120 \mathrm{~min}$ after oral administered $2 \mathrm{~g} / \mathrm{kg}$ glucose solution. The value of the area under the curve (AUC) was computed as follows: $\mathrm{AUC}=0.5 \times\left(\mathrm{G}_{0 \mathrm{~h}}+\mathrm{G}_{0.5 \mathrm{~h}}\right) \times 0.5+$ $0.5 \times\left(\mathrm{G}_{2 \mathrm{~h}}+\mathrm{G}_{0.5 \mathrm{~h}}\right) \times 1.5$. At the end of the experiment, rats were given anesthesia with $10 \%$ chloral hydrate $(0.3 \mathrm{~mL} / 100 \mathrm{~g})$, then the blood samples were withdrawn from abdominal aorta of rats. Then collected serum by centrifugation at 2500rpm at $4^{\circ} \mathrm{C}$ for $10 \mathrm{~min}$, and stored at $-20^{\circ} \mathrm{C}$ for TC, TG, LDL-C, HDL-C and serum insulin analysis. The atherosclerosis index (AI)was analysed as follows: $[\mathrm{AI}=(\mathrm{TC}-\mathrm{HDL}-\mathrm{C}) / \mathrm{HDL}-\mathrm{C}]$ (Chen et al., 2011). The liver, spleen, hymus and pancreas were immediately separated, then organ index (liver index, spleen index, thymus index) were calculated according to the formula [organ index $=$ fresh weight of organs $(\mathrm{mg}) /$ body weight $(\mathrm{g})]$. Pathological histology of pancreas and liver were measured after hematoxylin and eosin (HE)staining. The partial liver tissues stored in liquid nitrogen until further analysis.

\subsection{Statistical analysis}

The measurement data were expressed as mean value \pm standard deviation $(\bar{x} \pm \mathrm{SD})$. Single factor analysis of variance used $\mathrm{R}$ version 3.5.3 software (open source), statistical significant difference between the groups.

\section{Results and discussion}

\subsection{Effect of the aqueous okra extract on feed intake, water intake, urine volume, urine sugar and weight of rats}

The growth indicators as depicted in Figure $1 \mathrm{~A}-\mathrm{C}$, the average feed intake of $\mathrm{CK}, \mathrm{CKO}, \mathrm{M}$ and $\mathrm{MO}$ group were $21.7 \mathrm{~g}, 21.2 \mathrm{~g}$, $43.0 \mathrm{~g}$ and $39.6 \mathrm{~g}$, respectively. Feed intakes of diabetic rats were about twice as much as normal animals. Compared with the $\mathrm{M}$ group, the feed intake in the MO group decreased significantly in the third week $(\mathrm{p}<0.05)$. The average water intake of CK, CKO, M and MO group were $23.0 \mathrm{~g}, 21.4 \mathrm{~g}, 149.2 \mathrm{~g}$ and $142.4 \mathrm{~g}$, respectively. Compared with $\mathrm{M}$ group, the water intake of $\mathrm{MO}$ group reduced 
slightly with no significant difference. As shown in Figure1 C, the urine volume of normal rats (CK group and CKO group) were $3.5-7.5 \mathrm{~mL} / \mathrm{d}$. The urine volume of diabetic rats (M group and MO group) were significantly increased to $15.0-19.5 \mathrm{~mL} / \mathrm{d}$, which were enhanced by more than 2 times. Compared with the $\mathrm{M}$ group, the urine sugar in $\mathrm{MO}$ group decreased significantly with the rate of decline $91.91 \%$. As exhibited in Figure1 D, there was no difference on the body weight of each group before the experiment. The body weight of MO was significantly increased in the 8th week of the experiment. Type 1 diabetic rat model is characterized by a specific destruction of the pancreatic $\beta$ cells with a single large dose of STZ (STZ has direct toxic effects on the pancreatic $\beta$ cells). It is consistent with the literature reporting the symptoms of hyperglycemia and weight loss in type 1 diabetes (Gero, 2010; Haluzik\& Reitman, 2004).

\subsection{Hypoglycemic effect of the aqueous extract of okra on STZ-induced diabetic rats}

The weekly changes of fasting blood glucose during experimental period (Table 1) showed that the fasting blood glucose of normal rats (CK group and CKO group) was stable between $4.8-6.1 \mathrm{mmol} / \mathrm{L}$, and that in the diabetic rats (M group and $\mathrm{MO}$ group) was over $20 \mathrm{mmol} / \mathrm{L}$.Compared with the $\mathrm{M}$ group, the fasting blood glucose of the MO group decreased by $10.11 \%$ in the eighth week. By comparing with diabetic mice group, $200 \mathrm{mg} / \mathrm{kg}$ b.w./d of rhamnogalacturonan purified from okra pod polysaccharide showed decreased blood glucose level(Liu et al., 2018). Polysaccharide was the main component of the water extract of okra, the hypoglycemic effect was consistent with the result in this paper.
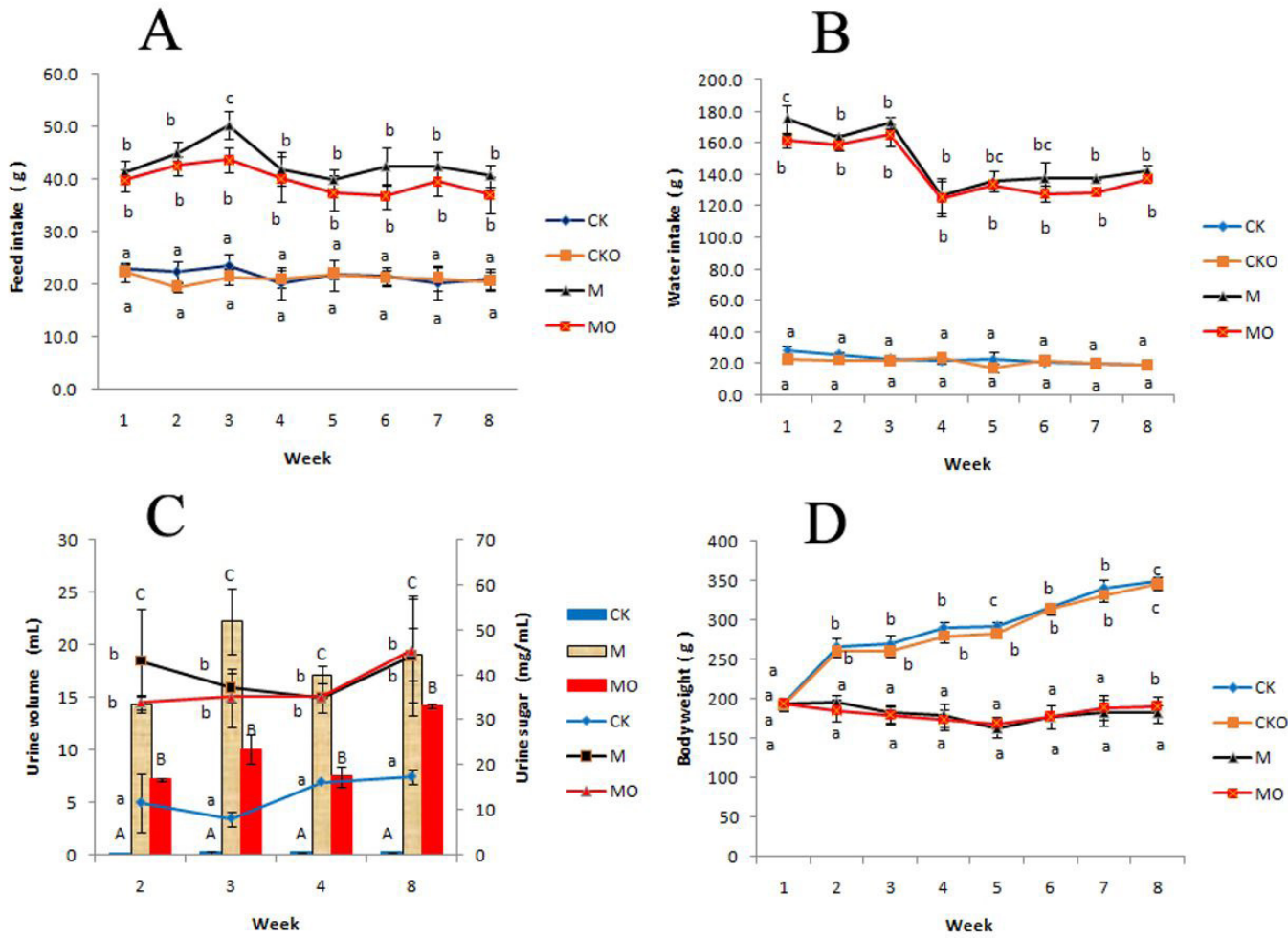

Figure 1. Effect of the aqueous okra extract on feed intake, water intake, urine volume, urine sugar and body weight of rats Lowercase letters compare means between treatments in the same week $(\mathrm{p}<0.05)$, Capital letters compare means between treatments in the same week $(\mathrm{p}<0.01)$. CK: Normal control group; CKO: Normal rats treated with okra aqueous extract group; M: Model control group; MO: Diabetic rats treated with okra aqueous extract group. A: Effect of the aqueous okra extract on feed intake. B: Effect of the aqueous okra extract on water intake. C: Effect of the aqueous okra extract on urine volume, urine sugar. D: Effect of the aqueous okra extract on body weight.

Table 1. Fasting blood glucose (FBG) table during gastric ravage.

\begin{tabular}{cccccc}
\hline week & CK & M & CKO & MO & Rate of decline \% \\
\hline 1 & $6.08 \pm 0.39 \mathrm{a}$ & $22.57 \pm 4.29 \mathrm{~b}$ & $5.85 \pm 0.42 \mathrm{a}$ & $21.73 \pm 3.79 \mathrm{~b}$ & - \\
2 & $5.97 \pm 0.49 \mathrm{a}$ & $25.7 \pm 1.15 \mathrm{~b}$ & $6.00 \pm 0.32 \mathrm{a}$ & $26.90 \pm 0.42 \mathrm{~b}$ & - \\
3 & $5.32 \pm 0.74 \mathrm{a}$ & $28.72 \pm 1.64 \mathrm{c}$ & $5.67 \pm 0.90 \mathrm{a}$ & $27.42 \pm 2.15 \mathrm{bc}$ & - \\
4 & $5.42 \pm 0.34 \mathrm{a}$ & $26.07 \pm 2.10 \mathrm{~b}$ & $5.62 \pm 0.52 \mathrm{a}$ & $26.66 \pm 2.34 \mathrm{~b}$ & 12.00 \\
5 & $4.80 \pm 0.14 \mathrm{a}$ & $25.55 \pm 4.37 \mathrm{~b}$ & $4.67 \pm 0.41 \mathrm{a}$ & $22.49 \pm 5.77 \mathrm{~b}$ & 10.71 \\
6 & $5.35 \pm 0.18 \mathrm{a}$ & $29.19 \pm 3.20 \mathrm{~b}$ & $5.70 \pm 0.43 \mathrm{a}$ & $26.07 \pm 1.90 \mathrm{~b}$ & 7.68 \\
7 & $5.18 \pm 0.67 \mathrm{a}$ & $27.73 \pm 1.38 \mathrm{~b}$ & $4.87 \pm 0.40 \mathrm{a}$ & $25.60 \pm 1.19 \mathrm{~b}$ & 10.05 \\
8 & $5.32 \pm 0.28 \mathrm{a}$ & $28.01 \pm 1.84 \mathrm{~b}$ & $5.38 \pm 0.39 \mathrm{a}$ & $25.20 \pm 1.22 \mathrm{~b}$ & \\
\hline
\end{tabular}

Note: Lowercase letters compare means between treatments in the same week $(p<0.05)$. CK: Normal control group; CKO: Normal rats treated with okra aqueous extract group; M: Model control group; MO: Diabetic rats treated with okra aqueous extract group. 


\subsection{Glucose Tolerance in Hyperglycemia Model Animals}

The results of glucose tolerance after four weeks showed as Table 2. Compared with the CK group, blood glucose and the area under the blood glucose curve of $\mathrm{MO}$ and $\mathrm{M}$ group at $2 \mathrm{~h}$ were significantly increased $(\mathrm{p}<0.05)$. Compared with the $\mathrm{M}$ group, the area under the blood glucose curve of the MO group was significantly reduced $(\mathrm{p}<0.05)$. The rate of decline was $12.00 \%$. $200 \mathrm{mg} / \mathrm{kg}$ b.w./d of rhamnogalacturonan showed decreased glucose tolerance in streptozotocin-induced diabetic mice(Liu et al., 2018).

\subsection{Dynamic changes of blood sugar in 24 hours after oral administration of aqueous extract of $\mathrm{Okra}$}

Blood sugar dynamic changes of rats gavaged with aqueous okra extract in 24 hours showed as Figure 2. Compared with the $\mathrm{M}$ group, the blood glucose of MO group at $0.5 \mathrm{~h}$ and $1 \mathrm{~h}$ were significantly decreased $(p<0.05) 7.74 \%, 5.00 \%$,respectively. Okra aqueous extract can reduce the peak of blood glucose value postprandial (within 2 hours).

\subsection{Organ index}

The organ index can be seen in Table 3. Compared with CK group, the liver index and thymus index of $\mathrm{M}$ group and $\mathrm{MO}$ group were significantly increased, while the spleen index was significantly reduced. Compared with $\mathrm{M}$ group, okra extract (MO group) has a tendency to ameliorate organ index, but there is no statistical significance.

\subsection{TC, TG, LDL-C, HDL-C and AI}

As shown in Table 4, serum TC, TG, HDL-C and AI in M group were significantly increased compared with CK group $(\mathrm{p}<0.01)$. Compared with the $\mathrm{M}$ group, TG of the MO group significantly decreased $(\mathrm{p}<0.05)$, with a decline rate of $41.59 \%$, while HDL-C was not significantly lower than that of the $\mathrm{M}$ group. Atherosclerosis index (AI) of MO group was significantly reduced ( $<<0.01$ ) 49.20\%. Serum triglyceride levels in high-fat diet-induced obese mice were significantly ameliorated by ethanol extract of okra (Fan et al., 2013; Fan et al., 2014). It was well known that blood glucose and lipid metabolism are inseparable (Zhou et al.,2019; Lv et al., 2019; Li et al.,2019), and the results of this article also supported this.

\subsection{Insulin (INS), hepatic glycogen and Pyruvate Kinase (PK)}

Table 5 shown that insulin and pyruvate kinase in M group was significantly reduced compared with that in CK group, while liver glycogen content was significantly increased. Compared with M group, insulin and pyruvate kinase activity of MO group increased significantly. The rate of increase reached $17.44 \%$ and $57.41 \%$, respectively. Okra extract (Tian et al., 2015), rich in antioxidant substances, could suppresses insulin resistance and regulating blood glucose level of gestational diabetes mellitus rats.

\subsection{The effects on morphology of rat hepatocytes}

As shown in Figure 3, in CK group and CKO group, liver cells were radically arranged around the blood vessel, forming hepatic cord and tightly arranged cells (Figure 3A,B). The liver

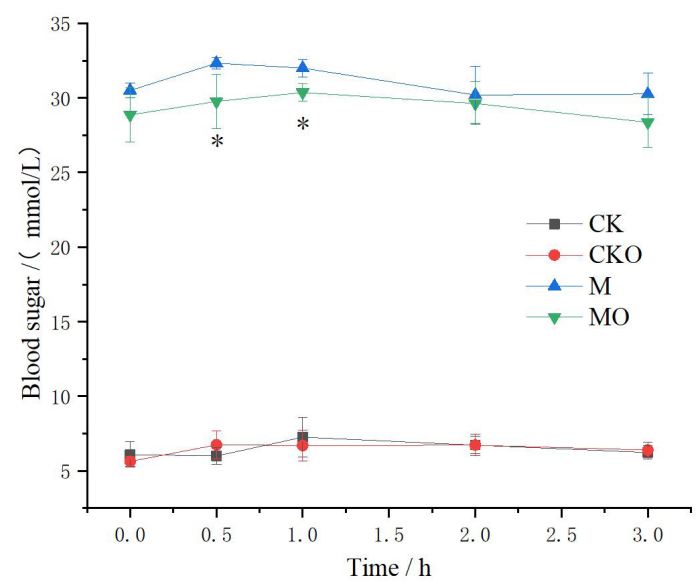

Figure 2. Effect of the aqueous okra extract on dynamic changes of blood glucose level in rats. ${ }^{*} \mathrm{p}<0.05$ vs. M. CK: Normal control group; CKO: Normal rats treated with okra aqueous extract group; M: Model control group; MO: Diabetic rats treated with okra aqueous extract group.

Table 2. Effects on glucose tolerance in glucose-induced hyperglucose.

\begin{tabular}{|c|c|c|c|c|}
\hline Group & $0 \mathrm{~h}(\mathrm{mmol} / \mathrm{L})$ & $0.5 \mathrm{~h}(\mathrm{mmol} / \mathrm{L})$ & $2 \mathrm{~h}(\mathrm{mmol} / \mathrm{L})$ & $\begin{array}{c}\text { Area under blood sugar } \\
\text { curve }[\mathrm{h} /(\mathrm{mmol} / \mathrm{L})]\end{array}$ \\
\hline CK & $4.80 \pm 0.14$ & $6.39 \pm 0.74$ & $5.57 \pm 0.73$ & $12.53 \pm 0.57$ \\
\hline M & $25.55 \pm 4.37$ & $30.56 \pm 2.15^{\star *}$ & $29.79 \pm 2.13^{\star *}$ & $57.40 \pm 0.93 * *$ \\
\hline $\mathrm{CKO}$ & $4.67 \pm 0.41$ & $5.66 \pm 0.69$ & $4.48 \pm 0.16^{\star}$ & $11.20 \pm 0.56^{\star}$ \\
\hline MO & $22.49 \pm 5.77$ & $27.57 \pm 1.36^{* *}$ & $26.20 \pm 2.34^{\star *}$ & $50.54 \pm 5.78^{* * \#}$ \\
\hline
\end{tabular}

Note: CK: Normal control group; CKO: Normal rats treated with okra aqueous extract group; M: Model control group; MO: Diabetic rats treated with okra aqueous extract group; ${ }^{*} \mathrm{p}<0.05 ;{ }^{* *} \mathrm{p}<0.01$ vs. Ck; \# $\mathrm{p}<0.05$.

Table 3. Rat organ index.

\begin{tabular}{ccc}
\hline Group & Liver index $(\mathrm{mg} / \mathrm{g})$ & Thymus index $(\mathrm{mg} / \mathrm{g})$ \\
\hline CK & $23.77 \pm 0.87$ & $1.69 \pm 0.08$ \\
M & $47.54 \pm 2.90^{* *}$ & $2.31 \pm 0.26^{* *}$ \\
CKO & $24.00 \pm 0.64$ & $1.73 \pm 0.08$ \\
MO & $44.24 \pm 2.76^{* *}$ & $0.64 \pm 0.14^{* *}$ \\
$1.06 \pm 0.10$ & $2.03 \pm 0.10^{* *}$ \\
\hline
\end{tabular}

Note: CK: Normal control group; CKO: Normal rats treated with okra aqueous extract group; M: Model control group; MO: Diabetic rats treated with okra aqueous extract group; ${ }^{* *} \mathrm{p}<0.01$ vs. Ck. 
Table 4. Effects of aqueous extract of okra on serum TC, TG, LDL-C, HDL-C and AI in diabetic rats.

\begin{tabular}{cccccc}
\hline Group & $\mathrm{TC}(\mathrm{mmol} / \mathrm{L})$ & $\mathrm{TG}(\mathrm{mmol} / \mathrm{L} /)$ & $\mathrm{LDL}-\mathrm{C}(\mathrm{mmol} / \mathrm{L})$ & HDL-C $(\mathrm{mmol} / \mathrm{L})$ & AI \\
\hline CK & $1.85 \pm 0.13$ & $0.82 \pm 0.10$ & $1.13 \pm 0.14$ & $0.35 \pm 0.02$ & $1.35 \pm 0.35$ \\
M & $2.65 \pm 0.44^{\star *}$ & $2.14 \pm 0.36^{* *}$ & $1.10 \pm 0.25$ & $0.50 \pm 0.07^{\star *}$ & $3.13 \pm 0.55^{\star *}$ \\
CKO & $1.95 \pm 0.30 \# \#$ & $0.96 \pm 0.08 \# \#$ & $1.22 \pm 0.18$ & $0.39 \pm 0.04$ & $1.50 \pm 0.31 \# \#$ \\
MO & $2.45 \pm 0.30^{* *}$ & $1.25 \pm 0.33 \#$ & $0.80 \pm 0.21$ & $0.44 \pm 0.02^{\star *}$ & $1.59 \pm 0.33 \# \#$ \\
\hline
\end{tabular}

Note: CK: Normal control group; CKO: Normal rats treated with okra aqueous extract group; M: Model control group; MO: Diabetic rats treated with okra aqueous extract group; ${ }^{* *} \mathrm{p}<0.01$ vs. Ck; \# $\mathrm{p}<0.05 ; \#$ p $<0.01$ vs .M.

Table 5. Effects of aqueous extract of okra on serum insulin (INS), hepatic glycogen and pyruvate kinase (PK) in rats.

\begin{tabular}{clcc}
\hline Group & INS(mIU/L) & Glycogen $(\mathrm{mg} / \mathrm{g})$ & PK vitality(U/g prot) \\
\hline CK & $26.17 \pm 0.51$ & $20.52 \pm 0.58$ & $17.69 \pm 1.77$ \\
M & $17.71 \pm 1.20^{* *}$ & $36.56 \pm 4.16^{* *}$ & $9.11 \pm 1.74^{* *}$ \\
CKO & $25.83 \pm 0.43 \# \#$ & $21.05 \pm 1.59$ & $14.50 \pm 1.20^{\star \# \#}$ \\
MO & $20.80 \pm 0.85 \#$ & $35.00 \pm 5.95^{\star *}$ & $14.34 \pm 0.94^{* *} \#$ \\
\hline
\end{tabular}

Note: CK: Normal control group; CKO: Normal rats treated with okra aqueous extract group; M: Model control group; MO: Diabetic rats treated with okra aqueous extract group;
${ }^{*} \mathrm{p}<0.05 ;{ }^{* *} \mathrm{p}<0.01$ vs. Ck; $\# \mathrm{p}<0.05 ; \# \mathrm{p}<0.01$ vs. $\mathrm{M}$.
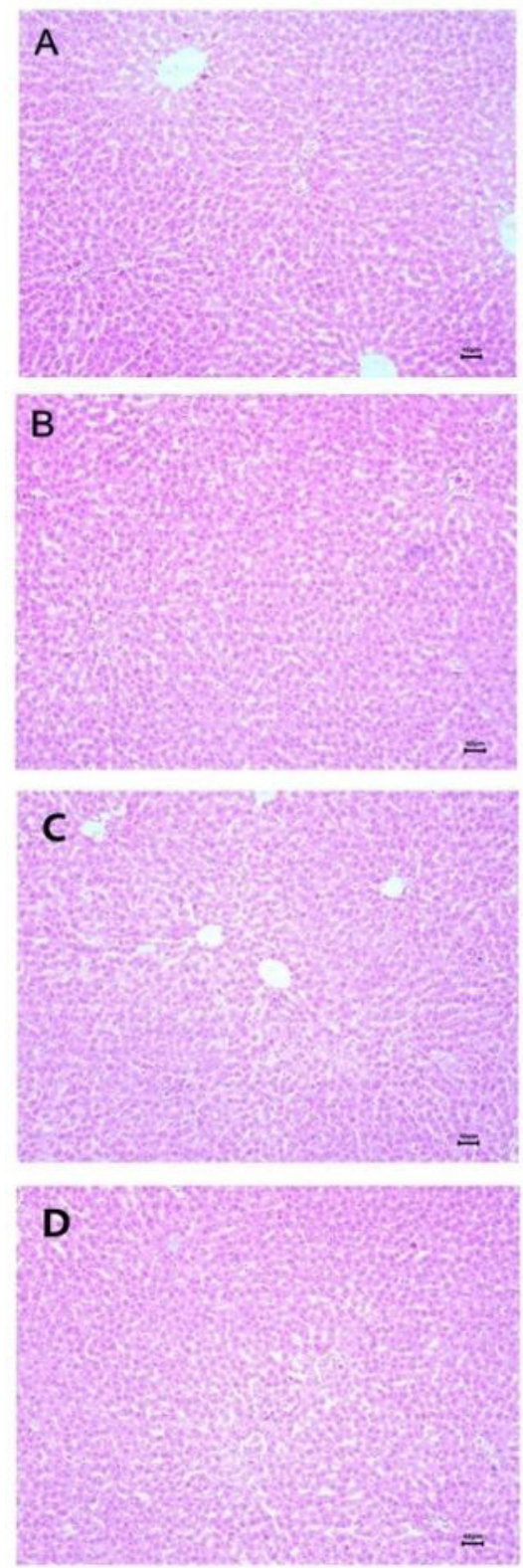
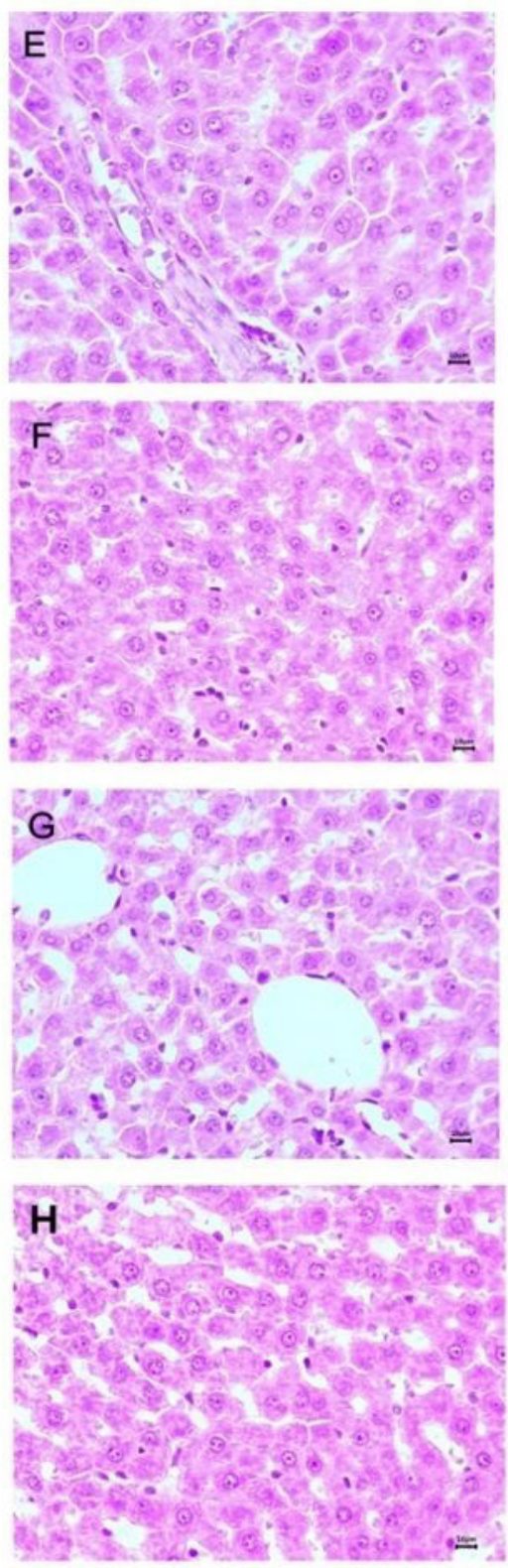

Figure 3. A-D: Structure of hepatic lobule $(10 \times 10)$; E-H: Morphology of hepatocyte $(40 \times 10)$. A,E: CK, normal control group; B, F: CKO, normal rats treated with okra aqueous extract group;, $\mathrm{G}$ : $\mathrm{M}$, model control group; $\mathrm{D}, \mathrm{H}$ : $\mathrm{MO}$, diabetic rats treated with okra aqueous extract group. 

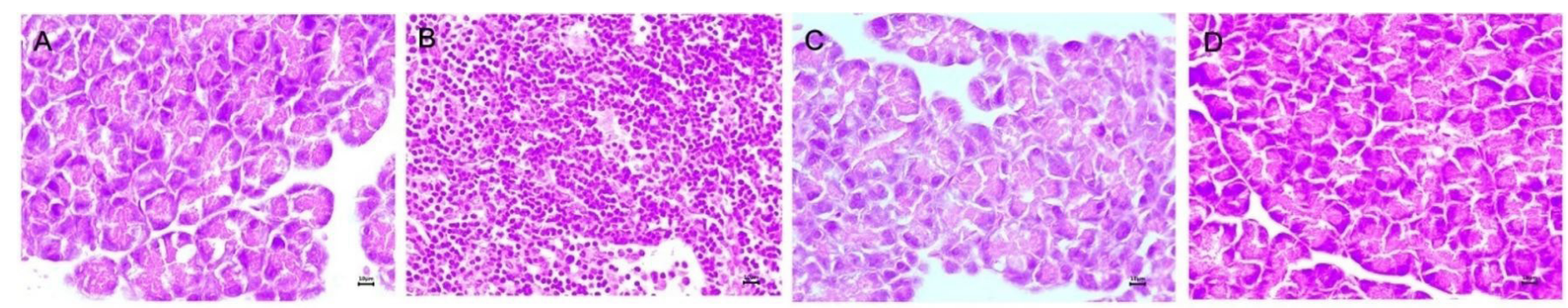

Figure 4. Morphology of pancreas. A: CK, Normal control group; B: CKO, Normal rats treated with okra aqueous extract group; C: M, Model control group; D: MO, Diabeticrats treated with okra aqueous extract group.

tissue structure of $\mathrm{M}$ group and $\mathrm{MO}$ group was intact, with liver cords arranged in disorder, liver cells arranged loosely, cell volume increased, and cytoplasm loose and under stained (Figure 3C, D). The liver cell has a large, round nucleus in the center, the cell boundaries were clear and there were no fat droplets in the liver cells (Fat droplets - dissolved in ethyl alcohol and xylene during preparation, forming vacuoles)(Figure 3E, F). The liver cells in group $\mathrm{M}$ were arranged in a disorderly manner, and round vacuoles of different sizes appeared in the cytoplasm, some of which were larger, squeezing the nucleus to the edge, and the cell boundaries were unclear or even fragmented (Figure 3G). Compared with $\mathrm{M}$ group, the hepatic lobules and steatosis in MO group were significant ameliorated: the nucleus was close to the center, there were cell boundaries, and the area of vacuoles was significantly reduced (Figure 3H).In Fan's report, total triglyceride and liver morphology in the mice were significantly ameliorated by an ethanol extract of okra treatment(Fan et al., 2014).It is consistent with the result of the effect of aqueous okra extract on total triglyceride and liver morphology.

\subsection{The impact on the rat pancreas fatty degeneration}

Compared with normal rats (CK group), diabetic rats (M group) showed obvious pathological changes in pancreas, with fatty degeneration (vacuole) and foci of fat distribution, which were mostly seen in the septa of pancreatic lobule(Figure 4A,C). Compared with $\mathrm{M}$ group, the fat vacuole of islet cells in $\mathrm{MO}$ group was significantly improved(Figure 4B,D). Administration of green okra extract or purple okra extract in diabetic rats, $\beta$ cell pancreas destruction induced by STZ injection could be partly repaired(Anjani et al., 2018).

\section{Conclusion}

Feed intake, water intake, urine volume, urine sugar and blood glucose of STZ-induced type1diabetic rats were increased by 1 -folds, 6 -folds, 2 -folds, 80 -folds and 3 -folds, respectively; but weight was reduced by 0.5 -folds of those of normal rats. The okra aqueous extract were showed hypoglycemic and hypolipidemic activities on STZ-induced type 1 diabetic rats. The mechanism of regulation of glycolipid metabolism were promoting insulin secretion and increasing pyruvate kinase activity for postprandial. Our results suggest that okra may use as a dietary therapy for people at high risk of diabetes.

\section{Acknowledgements}

This work was supported by the National Key R\&D Program of China [Project No. 2018YFD0400203]; Fujian Provincial Department of Science and Technology, China [grant numbers 2018R1014-1, 2018R1014-6, 2019R1032-12, 2018J0101 and 2019J01116]; and Fujian Academy of Agricultural Sciences [grant numbers DEC201821204 and STIT2017-3-5].The specially discussing with Dr. H S Shen (IAET, FAAS, China) in regarding to experimental design and data analysis of okra extracts are gratefully acknowledged.

\section{References}

Adetuyi, F. O., \&Ibrahim, T. A. (2014). Effect of Fermentation Time on the Phenolic, Flavonoid and Vitamin C Contents and Antioxidant Activities of Okra (Abelmoschus esculentus) Seeds.Nigerian Food Journal, 32(2), 128-137. http://dx.doi.org/10.1016/S01897241(15)30128-4.

Anjani, P. P., Damayanthi, E., Rimbawan, \&Handharyani, E. (2018). Antidiabetic potential of purple okra (Abelmoschus esculentus L.) extract in streptozotocin-induced diabetic rats.IOP Conference Series: Earth and Environmental Science, 196, 1-11. http://dx.doi. org/10.1088/1755-1315/196/1/012038

Chen, G., Luo, Y. C., Ji, B. P., Li, B., Su, W., Xiao, Z. L., \&Zhang, G. Z. (2011). Hypocholesterolemic effects of Auricularia auricula ethanol extract in ICR mice fed a cholesterol-enriched diet.Journal of Food Science and Technology, 48(6), 692-698. http://dx.doi.org/10.1007/ s13197-010-0196-9. PMid:23572806.

Deters, A. M., Lengsfeld, C., \&Hensel, A. (2005). Oligo- and polysaccharides exhibit a structure-dependent bioactivity on human keratinocytes in vitro.Journal of Ethnopharmacology, 102(3), 391-399. http://dx.doi. org/10.1016/j.jep.2005.06.038. PMid:16111846.

Fan, S., Guo, L., Zhang, Y., Sun, Q., Yang, B., \&Huang, C. (2013). Okra polysaccharide improves metabolic disorders in high-fat diet-induced obese C57BL/6 mice.Molecular Nutrition \& Food Research, 57(11), 2075-2078. http://dx.doi.org/10.1002/mnfr.201300054. PMid:23894043.

Fan, S., Zhang, Y., Sun, Q., Yu, L., Li, M., Zheng, B., Wu, X., Yang, B., Li, Y., \&Huang, C. (2014). Extract of okra lowers blood glucose and serum lipids in high-fat diet-induced obese C57BL/6 mice.The Journal of Nutritional Biochemistry, 25(7), 702-709. http://dx.doi. org/10.1016/j.jnutbio.2014.02.010. PMid:24746837.

Fellinger, P., Fuchs, D., Wolf, P., Heinze, G., Luger, A., Krebs, M., \&Winhofer, Y. (2019). Overweight and obesity in type 1 diabetes equal those of the general population. Wiener KlinischeWochenschrift, 131(3-4), 55-60. http://dx.doi.org/10.1007/s00508-018-1434-9. PMid:30617710. 
Food and Agriculture Organization of the United Nations - FAO. (2017). Rome, Italy: FAO. Retrieved from http:/fao.org/faostat/ en/\#data/QC.

Gao, H., Zhang, W., Wang, B., Hui, A., Du, B., Wang, T., Bian, H., \&Wu, Z. (2018). Purification, characterization and anti-fatigue activity of polysaccharide fractions from okra (Abelmoschus esculentus (L.) Moench).Food \& Function, 9(2), 1088-1101. http://dx.doi. org/10.1039/C7FO01821E. PMid:29359209.

Georgiadis, N., Ritzoulis, C., Sioura, G., Kornezou, P., Vasiliadou, C., \&Tsioptsias, C. (2011). Contribution of okra extracts to the stability and rheology of oil-in-water emulsions.Food Hydrocolloids, 25(5), 991-999. http://dx.doi.org/10.1016/j.foodhyd.2010.09.014.

Gero, L. (2010). Type 1 diabetes mellitus: pathogenesis, symptoms and therapy.OrvosiHetilap, 151(13), 533-539. http://dx.doi.org/10.1556/ OH.2010.28836. PMid:20304746.

Guo, W., Pan, Y., Li, L., Li, T., Liu, B., \&Lv, X. (2018). Ethanol extract of Ganoderma lucidum ameliorates lipid metabolic disorders and modulates gut microbiota composition in high-fat diet fed rats. Food \& Function, 9(6), 3419-3431. http://dx.doi.org/10.1039/ C8FO00836A. PMid:29877551.

Haluzik, M., \&Reitman, M. L. (2004). Animal Models of Diabetes. Diabetic Medicine. 22(4), 359-370. http://dx.doi.org/10.1111/j.14645491.2005.01499.x

Kahlon, T. S., Chapman, M. H., \&Smith, G. E. (2007). In vitro binding of bile acids by okra, beets, asparagus, eggplant, turnips, green beans, carrots, and cauliflower. Food Chemistry. 103(2), 676-680.

Hu, R., Guo, W., Huang, Z., Li, L., Liu, B., \&Lv, X. (2018). Extracts of Ganoderma lucidum improve lipid metabolism and modulate gut microbiota in high-fat diet fed rats.Journal of Functional Foods, 46, 403-412. http://dx.doi.org/10.1016/j.jff.2018.05.020.

Lee, B. R., Lee, Y. P., Kim, D. W., Song, H. Y., Yoo, K. Y., Won, M. H., Kang, T. C., Lee, K. J., Kim, K. H., Joo, J. H., Ham, H. J., Hur, J. H., Cho, S. W., Han, K. H., Lee, K. S., Park, J., Eum, W. S., \&Choi, S. Y. (2010). Amelioration of streptozotocin-induced diabetes by Agrocybechaxingu polysaccharide.Molecules and Cells, 29(4), 349354. http://dx.doi.org/10.1007/s10059-010-0044-9. PMid:20213314.

Li, L., Guo, W., Zhang, W., Xu, J., Qian, M., Bai, W., Zhang, Y., Rao, P., Ni, L., \&Lv, X. (2019). Grifolafrondosa polysaccharides ameliorate lipid metabolic disorders and gut microbiota dysbiosis in high-fat diet fed rats.Food \& Function, 10(5), 2560-2572. http://dx.doi. org/10.1039/C9FO00075E. PMid:30994668.

Lillioja, S. (1999). Diagnosing diabetes mellitus.Clinical \& Experimental Optometry, 82(2-3), 47-54. http://dx.doi.org/10.1111/j.1444-0938.1999. tb06752.x. PMid:12482292.

Liu, J., Zhao, Y., Wu, Q., John, A., Jiang, Y., Yang, J., Liu, H., \&Yang, B. (2018). Structure characterisation of polysaccharides in vegetable "okra" and evaluation of hypoglycemic activity.Food Chemistry, 242, 211-216. http://dx.doi.org/10.1016/j.foodchem.2017.09.051. PMid:29037680.

Lv, X., Guo, W., Li, L., Yu, X., \&Liu, B. (2019). Polysaccharide peptides from Ganoderma lucidum ameliorate lipid metabolic disorders and gut microbiota dysbiosis in high-fat diet-fed rats.Journal of Functional Foods, 57, 48-58. http://dx.doi.org/10.1016/j.jff.2019.03.043.

Moïse, M. M., Benjamin, L. M., Doris, T. M., Dalida, K. N., \&Augustin, N. O. (2012). Role of Mediterranean diet, tropical vegetables rich in antioxidants, and sunlight exposure in blindness, cataract and glaucoma among African type 2 diabetics.International Journal of Ophthalmology, 5(2), 231-237. http://dx.doi.org/10.3980/j.issn.22223959.2012.02.23. PMid:22762057.

O'Callaghan, S. (2017). Diagnosing Diabetes Mellitus.Physician Assistant Clinics, 2(1), 1-12. http://dx.doi.org/10.1016/j.cpha.2016.08.003.

Sabitha, V., Ramachandran, S., Naveen, K. R., \&Panneerselvam, K. (2011). Antidiabetic and antihyperlipidemic potential of Abelmoschus esculentus (L.) Moench. in streptozotocin-induced diabetic rats. Journal of Pharmacy \&Bioallied Sciences, 3(3), 397-402. http://dx.doi. org/10.4103/0975-7406.84447. PMid:21966160.

Sardá, F. A. H., Giuntini, E. B., Nazare, J.-A., König, D., Bahia, L. R., Lajolo, F. M., \&Menezes, E. W. (2018). Effectiveness of carbohydrates as a functional ingredient in glycemic control.Food Science and Technology (Campinas), 38(4), 561-576. http://dx.doi.org/10.1590/ fst.42517.

Sahoo, P. K., \&Srivastava, A. P. (2002). PH-Postharvest Technology. Biosystems Engineering, 83(4), 441-448. http://dx.doi.org/10.1006/ bioe.2002.0129.

Shaw, J. E., Sicree, R. A., \&Zimmet, P. Z. (2010). Global estimates of the prevalence of diabetes for 2010 and 2030.Diabetes Research and Clinical Practice, 87(1), 4-14. http://dx.doi.org/10.1016/j. diabres.2009.10.007. PMid:19896746.

TangB. S., LaiP. F., WuL., LiY. B., ShenH. S., \&Junchen, C. (2017). Recipe optimization and in vitro antioxidant properties of wheat bran dietary fiber chewable tablets. Food Science, 38(24), 171-176. http://dx.doi.org/10.7506/spkx1002-6630-201724027

The State Food and Drug Administration. (2012). Notice on the issuance of nine health function evaluation methods such as the evaluation of antioxidant function (National Food and Drug Administration No. 107). http://www.eshian.com/laws/9146.html.

Tian, Z. H., Miao, F. T., Zhang, X., Wang, Q. H., Lei, N., \&Guo, L. C. (2015). Therapeutic effect of okra extract on gestational diabetes mellitus rats induced by streptozotocin.Asian Pacific Journal of Tropical Medicine, 8(12), 1038-1042. http://dx.doi.org/10.1016/j. apjtm.2015.11.002. PMid:26706676.

Weng, M. J., Chen, J. C., Shen, H. S., Lai, P. F., \&Li, Y. B. (2017). A review on utilizations of Okra extracts for food, medicine and environmental protection.Fujian Journal of Agricultural Sciences, 32(6), 685-690. http://dx.doi.org/10.19303/j.issn.1008-0384.2017.06.020.

Yuan, Q., Lin, S., Fu, Y., Nie, X. R., Liu, W., Su, Y., Han, Q. H., Zhao, L., Zhang, Q., Lin, D. R., Qin, W., \&Wu, D. T. (2019). Effects of extraction methods on the physicochemical characteristics and biological activities of polysaccharides from okra (Abelmoschus esculentus).International Journal of Biological Macromolecules, 127, 178-186. http://dx.doi.org/10.1016/j.ijbiomac.2019.01.042. PMid:30639655.

Zhou, W., Guo, R., Guo, W., Hong, J., Li, L., Ni, L., Sun, J., Liu, B., Rao, P., \&Lv, X. (2019). Monascus yellow, red and orange pigments from red yeast rice ameliorate lipid metabolic disorders and gut microbiota dysbiosis in Wistar rats fed on a high-fat diet. Food \& Function, 10(2), 1073-1084. http://dx.doi.org/10.1039/C8FO02192A. PMid:30720827. 